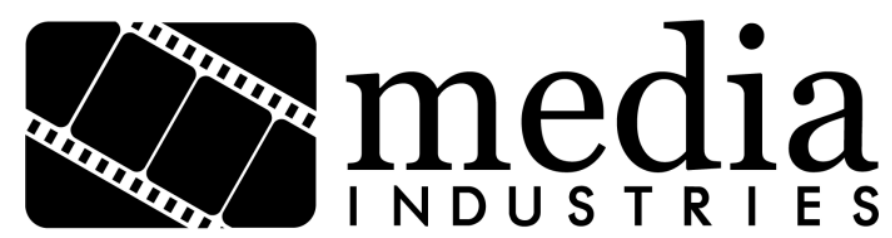

\title{
PR and Politics at Hollywood's Biggest Night: The Academy Awards and Unionization (1929-1939)
}

Monica Sandler ${ }^{1}$

University of California, Los Angeles

msandler27 [AT] ucla.edu

\begin{abstract}
:
In 1933, after an attempt by studio heads to implement major wage cuts and contract reforms in the height of the Great Depression, an unlikely institution became intertwined with the politics of Hollywood unionization: the Academy Awards. As the screen actors', writers', and directors' guilds struggled to gain collective bargaining rights from studio heads, the awards, which were created as a wider PR effort for the industry as a whole, became a negotiation tactic harnessed by unions through a series of boycotts and well-placed articles as they fought producers into the end of the decade. Through a detailed study of Academy internal memos and trade journal discourse, this essay chronicles the awards during the 1930s to examine how the award ceremony's promotional eminence contributed to Hollywood unionization.
\end{abstract}

Keywords: Labor, Hollywood, Historiography, Political Economy

Live from the Biltmore Hotel in downtown Los Angeles, the eleventh annual Academy Awards were a night filled with "twelve hundred of Hollywood's finest - all beautifully gowned and carefully groomed." 2 Yet only days earlier, the ceremony was almost cancelled - inadvertently intertwined in cross-studio workers' relations politics. The Screen Directors Guild (SDG) had been steeped in conflict with studio producers for months, seeking collective bargaining rights to serve as the union representing film directors and assistant directors. A week before the ceremony, negotiations began to break down once again. Frank Capra explains in his autobiography: "We discussed possible power moves. Some members were for calling an emergency meeting of all directors and asking for a strike vote . . . I suggested a more immediate power play: disrupt the upcoming Academy Awards banquet." 3 Capra at this time was president of both the Academy of Motion Pictures Arts and Sciences (AMPAS) and SDG. He proposed a boycott of the event by all directors, and declared that he would resign from any involvement in AMPAS, including his upcoming job as the Oscars' master of ceremonies. Within a day, producers yielded to Capra's demands, and SDG gained bargaining rights as a union - all resulting from a mere threat to usurp the Academy Awards. 
Founded in 1929 as a ceremony to give out trophies and further market winning films, the Academy Awards grew into a Hollywood institution during the 1930s. Capra served as president of AMPAS from 1935 to 1939 and was instrumental to the awards' development in the latter part of the decade, an era during which the event proved to be an invaluable tool not only for raising ticket sales but also for influencing industry policy. The incident in 1939 was not the only time the Academy Awards were held in the middle of employee conflicts. Throughout the decade, the screen actors, writers, and directors guilds used a series of ceremony boycotts and well-placed articles denouncing producers to force new contract negotiations. The awards, created as a wider public relations effort for the industry as a whole, instead became a publicity battleground used by Hollywood unions as they fought producers for labor rights in the latter half of the 1930s. Especially under the leadership of Frank Capra, the awards served to consolidate the power of the unions and simultaneously grew the event's size and stature into an institution key to the Hollywood economy.

This research emerges from archival papers found directly at the AMPAS Herrick Library and through a close investigation of written entertainment-news outlets from the era. It intends to add insight to previous studies on unionization in Hollywood by examining the awards' role as a popular culture forum that was closely linked to labor starting with its founding in 1929. Academic writing on unionization during the 1930s, such as Ross Murray's seminal Stars and Strikes and The Inquisition in Hollywood by Larry Ceplair and Steven Englund, discusses AMPAS's involvement in unionization through an examination of their failed Conciliations Committee. ${ }^{4}$ Danae Clark's Negotiating Hollywood also notes the award's relationship to the Screen Actors Guild. ${ }^{5}$ These records cite direct threats on the annual Academy Awards ceremony as major turning points in labor recognition negotiations. Little, however, is written directly about the position of the Academy and the awards in the industry during this period. Pierre Norman Sands's A Historical Study of the Academy of Motion Picture Arts and Sciences (1927-1947), though written in the 1970s, continues to provide the most detailed account of the development of AMPAS during its first twenty years. ${ }^{6}$ Recent historiographic studies like Peter Decherney's Hollywood and the Cultural Elite have raised issues about the importance of cultural institutions like the awards within labor issues during the 1920s and '30s, examining the link between big business and artistic institutions such as New York's Museum of Modern Art.7 This article hopes to study the awards as what Decherney refers to as "Hollywood's canon-building ceremony," to look at its relationship to commerce, unionization, and notions about artistic expression in Hollywood through a direct examination of primary documents. ${ }^{8}$

\section{Introducing the Academy of Motion Picture Arts and Sciences and Its "Awards for Merit"}

The Academy Awards grew out of an early AMPAS goal to be a forum that represented the public image of American film. The Academy was created at a time when "attacking Hollywood was the favorite indoor sport of reform organizations and censorship groups," yet "there was no unified voice representing the entire industry to speak out against these attacks." 9 AMPAS would be a cohesive group designed for the betterment of the industry as a whole, both as tool for discourse among different departments in film production and as a public relations platform to represent Hollywood to the American media. A pamphlet from the AMPAS founding banquet explains the intentions of the new organization:

For many years, you and we of the creative forces in this industry have left to others the promotion and protection of our interests. Collectively, we have done nothing effective either to harmonize and correct conditions within our own 
ranks or to cooperate for the welfare of the industry as a whole. If we producing workers, actors, directors, technicians, cinematographers and producing executives, who have the future progress of this great universal entertainment at heart, will now join unselfishly into one big concerted movement . . . We can promote harmony and solidarity among our membership and among our different branches. We can reconcile any internal differences that may exist or arise. We can adopt such ways and means as are proper to further the welfare and protect the honor and good repute of our profession. ${ }^{10}$

At its creation, AMPAS was an almost entirely American-based film organization, featuring only international talent, like Charlie Chaplin, who worked in the United States as well as outside the country. ${ }^{11}$ The focus of the Academy was to protect the interests of employees in the Hollywood filmmaking business.

One of the Academy's key functions at its founding was to serve as an industry mouthpiece for wider national issues. Throughout the 1920s, conservative groups such as the Christian Endeavor Society denounced Hollywood as unscrupulous, and congressional hearings questioned Hollywood's morality overall. One record provides testimony stating:

At Hollywood is a colony of these people where debauchery, riotous living, drunkenness, ribaldry, dissipation, [and] freelove seem to be conspicuous . . . These are some of the characters from whom the young people of today are deriving a large part of their education, views of life, and character forming habits. From these sources our young people gain much of their views of life, inspiration and education. Rather a poor source not? It looks as if censorship is needed, does it not? ${ }^{12}$

In challenge to this growing censorship movement, the Academy's founding literature announced that it would "take aggressive action in meeting outside attacks that are unjust." 13 The early work of AMPAS closely aligned itself with the Motion Picture Producers and Distributors of America (MPPDA), more commonly known as the Hays Office, to provide a unified image of Hollywood in wake of these regulation threats. One of the Academy's first PR projects helped the MPPDA launch their first regulation code in 1927, serving to mediate the national discussion over the new industry-wide content restrictions. ${ }^{14}$ AMPAS also developed welfare and education programs to highlight a more positive view of the film industry. For example, AMPAS was instrumental to the launch of the first film production curriculums at schools like the University of Southern California. ${ }^{15}$

The "Awards of Merit" were the largest event developed for these early purposes in Hollywood publicity relations. They were designed both as a distinct recognition honoring filmic achievement and as a national media platform. The ceremony traded on public interest in celebrity while celebrating and encouraging an image of Hollywood that highlighted the technical artistry of the medium. The Academy Awards quickly gained national attention in newspapers and fan magazines alike and brought financial benefits to producers who were able to rerelease winning films for considerable profit. It was immediately the biggest performing arts awards of its day, as other filmic honors generally circulated within "best of year" lists in magazines, and could be seen as most contemporarily aligned to existing literary distinctions like the Pulitzer Prize (established in 1917), which focused on excellence in the craft of writing while raising awareness for winning authors and texts. ${ }^{16}$ There was almost instantaneous interest in winning an Oscar statuette among the Hollywood actors, writers, directors and film 
technicians who were being offered new achievements (and resulting pay increases) for outstanding work. ${ }^{17}$ As stars began to congregate at the event, it annually became a more and more glamorous representation of a Hollywood meritocracy. It was a night of beauty, fashion, celebrity, and artistic achievement-everything that film executives wanted Hollywood to embody.

\section{The Rise and Fall of the AMPAS Conciliations Committee}

The beginning period of AMPAS's development, from 1927 until 1933, was most focused on carving out a role in labor relations. The Academy created a Conciliations Committee to "aid and encourage the development of the production branches of the motion picture industry by coordinating the forces in constructive and cooperative action."18 It was a court for workers to raise employment-related issues, developed just as unionization was on the rise in Hollywood. In 1926, film technicians had successfully unionized within the International Alliance of Theatrical Stage Employees (IATSE) and secured rights as a labor bargaining agent with the Association of Motion Picture Producers (AMPP). ${ }^{19}$ While at this time groups like the Screen Writers Guild and the movie division of Actors' Equity existed for more specialized employee groups, their membership did not yet represent a majority of the studio workforce. ${ }^{20}$ Producers, however, feared that these groups would be the next to properly organize. The Academy was created to be a loosely formed commission divided into departments of producers, directors, writers, actors, and technicians. Each branch could file complaints to producers, but without the bargaining rights of a fully formed union. Up until 1933, this Conciliations Committee acted as the primary labor negotiating forum for writers and actors, hearing hundreds of worker disputes and securing a standard contract agreement, a feat that existing guilds had failed to accomplish through the 1920s. ${ }^{21}$

Despite these labor accomplishments and expansive mission statement, the Academy represented only a small minority of the working body in Hollywood. As it is today, entrance into the Academy was only by invitation, to be granted to "any person who has accomplished distinguished work or acquired distinguished standing in or made a valuable contribution to the production branches of the motion picture industry"; the organization was exclusive, with participants chosen "by vote of the Board of Directors, on recommendation of the Committee on Membership." 22 At its founding, the Academy had only 231 members; at its largest early point, in 1932, it had just over 800 members. ${ }^{23}$ While any employee working in the film industry could file a grievance through the Conciliations Committee, only members were able to represent and help determine complaint outcomes. As "the highest distinction attainable in the motion picture profession," the awards continued in this elitist tradition. ${ }^{24}$ Becoming an awards nominee was often the easiest way to be granted membership into AMPAS and be able to participate directly in Hollywood conciliations.

These issues regarding representation within the Academy became a major source of conflict in the 1930s as the organization struggled to mediate the growing financial difficulties incurred within the studios during the Great Depression. Starting in 1933, New Deal legislation had major effects in Hollywood. On March 6, just hours after his inauguration, President Franklin Roosevelt issued Proclamation 2039, requiring all banks nationwide to close and suspend all monetary transactions for a week. ${ }^{25}$ Along with the bankers, corporations throughout the country, including Hollywood movie studios, were forced to close, relying on bank transactions and financing to conduct day-to-day business. During this week off, producers across company lines met to discuss financial issues facing the industry as a whole; nearly every production 
office was on the verge of bankruptcy and operating on government credit. Within a day of the national bank closing, AMPP issued industry-wide budget cuts, slashing hourly income rates and benefits to its employees. ${ }^{26}$ The conciliations arm of AMPAS was intricately involved in negotiations with producers following these cutbacks. Soon after the national banks and studios reopened on March 13, an Emergency Committee was formed within the Academy to review studio finances and to prevent companies from permanently closing. While Academy forces tried to arbitrate compromise over these wage-cut issues, their labor system could merely suggest policy and could not organize bargaining tactics, like strikes, that would force diplomacy. Producers simply ignored Academy initiatives pertaining to financial planning matters.

AMPAS's failure to mitigate the financial crisis resulted in a resurgent interest in unionization across the film industry. On April 16, 1933, the Screen Writers Guild (SWG) held a reorganization meeting. A fledgling labor group until this point, it was reassembled to present a united front against the pay cuts. In October, following the attempt by AMPP to create a more binding contract that included salary caps for celebrities, performers formed the Screen Actors Guild (SAG). ${ }^{27}$ These unionization efforts, while very much a response to producers' wage cuts, were also motivated by new government legislation under President Roosevelt. In June, Congress passed the National Industrial Recovery Act (NIRA), devoted to economic recuperation for the country through deep oversight and regulation by government committees. ${ }^{28}$ The bill entitled employees to "the right to organize and bargain collectively [with a] representative of their own choosing . . . free from the interference, restraint, or coercion of employers." 29 The law started a national movement of unionization efforts within the country; established unions rapidly gained membership, while new bargaining organizations such as the American Newspaper Guild and the United Mine Workers of America were launched in their respective business sectors.

The development of SWG and SAG in the film industry happened within this same yearlong span and had drastic effects on the Academy. Both SAG and SWG instituted policies that any person joining the unions should resign from AMPAS. Within months, the Academy lost over half of its membership and its "monthly income was reported at \$900 less than its monthly expenses cut to their lowest point." 30 The Academy had been funded through membership dues and donations made by studio heads. As it proved ineffective for executing their agenda and negotiating with workers, producers also withdrew their money. Going into 1934, the Academy was in financial ruin.

\section{Awards Planning, Marketing, and Restructuring Strategies during AMPAS Crisis}

Despite conflicts with new unions, the 1934 Academy Awards event continued to be highly successful as a PR and fundraising device for AMPAS. The Hollywood Reporter wrote the day before the ceremony: "the big problem yesterday was the fact that there were many more reservations than there will be chairs." 31 Over 960 people, two hundred more than the initial restriction to 760 chairs, attended the awards. ${ }^{32}$ That year, "the awards" were added into the Academy bylaws' statement of purpose: the organization was now designed "to encourage the improvement and the advancement of the arts and sciences of our profession by the interchange of constructive ideas and by awards of merit for distinctive achievements." 33 This addition reflected the event's expanding role in the Academy as other departments began to falter. The success of the awards became a huge focus within AMPAS. For the next several years, as the Academy continued to oppose the unions, the awards were annually transformed, adding new 
rules and categories in order ensure successful financing for the event in the face of workforce animosity.

The lead-up to the awards ceremony in 1935 offers the first example of such strategic changes, however predominantly motivated by Hollywood gossip they were. Following the announcement of the nominees for the seventh Academy Awards, public outrage erupted over the omission of Bette Davis's performance in Of Human Bondage (1934) from the best actress category. Articles in fan magazines, the outlets that wrote the most continuous coverage about the annual event, turned negative as conversation ranged wider than the average annual arguments over whether each actress deserved her nomination. One Photoplay article explained: "even my postman lingered the other morning on the doorstep and pushed back his cap from a puckered brow. 'My son and I have been talking about this Academy passing up Bette Davis. It's a darn outrage . . . and I think Photoplay ought to give 'em the devil!'"34 Many of Davis's peers felt that her omission highlighted the producers' control over the Academy. Industry rumors intimated that Davis had lost the nomination for Bondage because of larger conflicts with her studio, Warner Bros. Pictures, 35 and that Jack Warner had discouraged Academy members from voting for her. ${ }^{36}$ Led by Joan Blondell (a fellow Warner-contracted actress), a group of performers demanded that Davis be reconsidered within her category. Blondell notes the impact of the incident within the acting community: "I suppose there was no chance for any part of the process to be fair because everybody had quit the Academy. But when they left Bette out, we all began taking a closer look and decided, 'hey, something's rotten in Beverly Hills.'" 37 At this time in 1935, the actors' branch had under a hundred members; the nominations and awards winners were decided by a small minority of professionals who had not withdrawn from AMPAS in the wake of SAG's mandate to do so. The Hollywood Citizen News explained: "the Academy is dwindling in importance, especially in Hollywood, and its current nominations have done much to harm it." 38 The backlash surrounding this Bette Davis nomination snub, involving both industry employees and news outlets alike, reflected a growing view that the Academy and its awards had outlived their usefulness as a public relations tool.

In the wake of this industry and media criticism, it was announced that a write-in option would be added to final voting ballots. A Variety article explained: "following a wave of criticism that arose over nominations for Academy Awards this year, the organization has changed its procedure of electing in order to allow the writing in of additional names by those members not satisfied with the nominees." The article also speculated that formal protests like Blondell's had an impact on this decision: "when the Acad board of governors learned of the threatened insurrection they called a hurried meeting and decided to legalize the "write-in' method." 39 Despite the many cries of foul play over the nominations, the new voting policy did not result in any radical changes to the eventual winners; only original contenders took home award trophies. The write-in option instead can be seen as a move by the Academy to appease public opinion: come awards night the event regained positive coverage in trade and fan magazines. In contrast to their earlier articles, Photoplay later wrote about the awards winners: "their selections indicated a real understanding of the purpose of the cinema; namely, entertainment . . . the Academy itself seemed entitled to some special mention for its clear-sighted recognition of what constitutes excellent screen fare." 40 Best picture went to It Happened One Night (1934), an already widely popular hit, and a special award was dedicated to Shirley Temple. This rule change calmed the media scandal and set precedents for awards organizers through the rest of the decade, annually redefining the event to appease and deflate new accusations directed at the 
Academy and ceremony itself. The write-in policy stayed in place until 1937, as AMPAS finally began to rekindle its relationship with unions.

After the controversy surrounding the seventh awards ceremony, the latter part of 1935 saw the rise of a new Academy spokesperson and the expansion of communications strategy surrounding the Oscars. In October of 1935, Frank Capra was elected AMPAS president. He had been a high-ranking member of the Academy's directors branch since 1931, serving on a wide range of the organization's planning committees; at the end of 1935, just coming off of his first Best Picture and Best Director wins, Capra was an ideal figurehead. ${ }^{41}$ Capra was instrumental in the Academy's policy changes through the period of his administration, which ended in 1939. One of his first moves as president was expanding the publicity department by hiring new people to specialize in handling awards coverage. ${ }^{22}$ That year AMPAS also first commissioned Price Waterhouse, a firm of public accountants, to count and verify all ballots and squelch any future claims of voter fraud; the company has remained the accounting partner for the Academy Awards into the present day. ${ }^{43}$

The results of these new planning efforts could be seen at the eighth Academy Awards. When union-wide directives discouraged attendance to the 1936 awards, the ceremony was changed to focus on a lifetime achievement award. Capra wrote in his autobiography: "to spur attendance, we countered by persuading the giant of all filmmakers D. W. Griffith to come out of his retired oblivion and to accept from the Academy a special statuette for his legendary pioneering in films." 44 This move motivated industry turnout, as former colleagues came to pay tribute to Griffith. While the event ultimately lacked star power due to the guild boycott, the banquet was actually "the biggest in the history of these functions." 45 Even prior to the announcement of the union embargo, the Awards Planning Committee had chosen a new ticketing policy: studio management had to buy tickets in bulk and distribute them to employees. ${ }^{46}$ With this method, it became the studios' problem to fill seats from the tickets they had already purchased. In the wake of guilds' refusal to participate, a vast group of lowerranking employees ultimately attended Oscar night, but all the seats were filled. Capra curbed the possibility of another boycott in 1937 by expanding the prize selection. That year saw the first addition of trophies for best supporting actor and actress, developed predominantly to spur interest within the acting community. ${ }^{47}$ These new rules and categories were each specifically intended to raise ceremony attendance.

\section{The Unions Fight Back at the Oscars}

The awards boycott in 1936 grew from two years of failed negotiations between producers, unions, and the existing AMPAS labor division. It was motivated both by the guilds' continued conflict with the Academy Conciliation Committee and as a means of pushing for new negotiations with producers. At this time the Conciliation Committee still maintained involvement in employment and contracting issues within Hollywood, directly in opposition to SAG, SWG, and the newly formed SDG, who were trying to gain the right to serve as the acknowledged representatives of their workforce. On March 2, a telegram was sent to SAG membership, stating: "the board feels that the Academy is defiantly inimical to the best interests of the Guilds, you should not attend." 48 The writers and directors guilds distributed similar messages. On the night of the ceremony, winners such as John Ford and Dudley Nichols publicly refused to attend the event. The day after, Nichols released a statement declining his best screenplay trophy for The Informer (1935): 
The Screen Writers Guild was conceived in revolt against the Academy and was born out of disappointment with the way it functioned against employed talent in any emergency. To accept the award is to tacitly support the Academy, and I believe it the duty of every screenwriter to stand with his own. ${ }^{49}$

Nichols was a board member of the SWG, and felt that it would be inappropriate to take an award given by an organization in direct opposition to his own guild.

While this boycott targeted the Academy for its overreach, it was also a statement to AMPP that the guilds would not associate with organizations they felt sympathized with producer interests. They hoped to hurt the ceremony economically and cause a media uproar similar to what surrounded the previous ceremony, when Bette Davis was snubbed. The boycott was actually very successful in raising public awareness for those complaints. Because it affected a major event in popular culture, the boycott was discussed not only in industry trade publications but also within fan magazines like Photoplay. These national news outlets noted the missing star power from the ceremony and then explained the union issues that led to their absence, declaring: "never has Hollywood been in more turmoil." 50 American movie viewers across the country read about the boycott because it was discussed within the context of the annual Oscar ceremony coverage of red carpet attire and celebrity.

Despite creating national awareness of these film industry labor issues, the boycott was not effective as a bargaining device with producers. AMPP had withdrawn funding efforts to the Academy in 1933 when the organization began to compete with more fully formed guilds. While producers had little interest in working with the unions, they no longer wanted to be involved with the AMPAS Conciliations Committee, which had consistently argued with their cost-saving measures since its founding; they, too, wanted the Academy to fold. Also, while the boycott did grab media attention, largely due to the planning measures instituted by Capra and the announcement of D. W. Griffith's lifetime achievement award, it never threatened to completely destroy the ceremony. The event still drew in the annual marketing attention for which it was designed. Following awards wins, even The Informer (1935), the film for which Dudley Nichols declined his award statue, saw a national rerelease and increased box office revenue. ${ }^{51}$ The guild's attack created unexpected publicity for the industry-producers had spun the boycott into a free marketing gimmick that increased ticket sales.

The boycott, however, also overlapped with legal battles between producers and guilds. As union lawsuits worked their way into the judicial system, producers maintained a consistent argument: that actors, writers, and directors were highly skilled artists rather than cooperative laborers; they cited the Academy Awards as a key component to this claim. A 1935 Variety article explains: the "lack of conclusive legal definition on this point threatens the validity of the arbitration clause in the standard player contracts written by the AMPAS, fogged temporarily by all conciliation awards made by the organization." 52 The awards were a legal issue because they celebrated individual artistic achievement, which producers felt was evidence that these artists were not common laborers and therefore had no place in a union. The classification of certain divisions of the workforce as artistic meant that each employee should be judged for payment and work requirements based on the value of his or her individually given talents, and this value could not be standardized for representation by cooperative organizations like unions. ${ }^{53}$ As the awards became a subject in court proceedings, the boycott publicly withdrew the guilds from their involvement with the now-contested event. ${ }^{54}$ 
This artistry argument was consistently shot down within the US court system; the National Labor Relations Board (NLRB) determined that regardless of the unique skill set of many industry departments, these groups represented employees of the studios, and their conditions of employment entitled them to be able to unionize. Rulings came on the grounds of the National Labor Relations Act, or Wagner Act, of 1935, which expanded the collective bargaining privileges first recognized in the NIRA and created the NLRB as a government board that could determine workers' rights on a case-by-case basis. ${ }^{55}$ The bill was legally contested until upheld by the Supreme Court on April 12, 1937, at which time there was a wave of contracting agreements signed between companies and labor unions across the country. Many corporate leaders, including Hollywood producers, had waited to see whether the Wagner Act would be overturned before providing restitution for any NLRB claims verdicts. 56 Soon after the Supreme Court decision, AMPP made its first labor concession (but only after the threat of a workers' strike), granting SAG a standard contract to be the union for film actors. ${ }^{57}$ The writers' and directors' groups, however, continued to fight producers for several more years.

In the wake of the Supreme Court decision on the Wagner Act, the Academy issued a directive announcing its withdrawal from all labor activity. Director W. S. Van Dyke, chair of the Reorganization Committee, wrote: "now for the first time we are free of all labor relations responsibility, permitting the Academy to return to its first principles and be non-economic and non-political in theory and in fact." 58 The intention of AMPAS going forward would be to exclude itself from Hollywood politics and return its focus to public relations, education, and goodwill directives. The Academy thereafter assumed a role confined "to publications of production statistics, including talent credits, the annual 'best performance' awards . . . and expanded the work of its Research Council." 59 For the next several years, AMPAS focused on repairing relationships with workers, both to restore the organization's membership and because of Frank Capra's growing involvement in SDG.

The tenth award ceremony, in March of 1938, highlighted the Academy's reconciliation with the guilds. The rules that year opened voting to members of SWG and SDG. Each group had an equal representation on the nominations committee, and the entire guild bodies were allowed to decide the final winners. In total, more than fifteen thousand people took part in the final balloting. The new policy "symbolized the friendly acclaim of those who are devoting their efforts to the creation of the greatest entertainment in the world, the motion picture." 60 On Oscar night, the guilds were officially represented at the ceremony by their presidents: Robert Montgomery for the actors, King Vidor for the directors, and Dudley Nichols for the writers. In a further show of reconciliation, Dudley Nichols accepted the Oscar for The Informer that he had turned down two years earlier. ${ }^{61}$

This voting policy, however, exposed cracks already existent within the guilds. After a nomination for Best Screenplay, Captains Courageous (1937) writer John Lee Mahin issued an open letter to Variety and The Film Daily (amongst other outlets), publicly withdrawing his name from consideration in the awards. He declared that "unfair discrimination had been practiced in the selection of the writers' branch awards committee." 62 He claimed that his union had been excluded from being a part of nominations committee because of its membership's political views; Mahin was president of Screen Playwrights Inc., a conservative organization that had splintered from the Screen Writers Guild in May 1936, claiming that the union was encouraging communism. While their body never exceeded seventy-five members, in 1936 producers contracted them to become the sole representative in bargaining rights for writers. This was met with widespread criticism because, like the Academy had been before, the Screen Playwrights 
represented only a small minority of the writing community. ${ }^{63}$ Later, in 1938, SWG, the largest screenwriters' representative, won certification from NLRB as the sole bargaining agent for screenwriters but continued to haggle for a final contract agreement for another two years. The exclusion of Screen Playwrights from that year's awards proceedings aligned AMPAS with SWG at a time when writers' unionization was still uncertain. This voting change served as a pro-union appeasement act, as the Academy passed over more producer-favored organizations. Through this coalition with unions and the open-voting initiative, by the end of 1937, AMPAS membership was restored to nearly the same size it had been in 1933.

As the Academy continued to restructure in 1938, it remained at the center of unionization issues--while claiming to be nonpartisan. AMPP had become highly interested in a thriving Academy, hoping to expand the financial benefits of the organization's public relations efforts. Producers like Darryl Zanuck and David O. Selznick attempted to dominate a Reorganization Committee filled with membership from each department and ranking union advocates. Quickly enough, "guild members felt the producers were asking for cultural cooperation, while at the same time refusing economic cooperation with the creative workers." 64 Around this same time, Frank Capra rose in the ranks to SDG president, now wielding power in two organizations whose interests often overlapped. Despite his tireless efforts to keep AMPAS from folding over the previous years, Capra now focused on securing rights for his union. In September of 1938, with conflict on the Reorganization Committee reaching a climax, Capra and chair William Van Dyke requested that AMPP members resign from the Academy Reorganization Committee and "turn control over to the workers." The threat was that "if the three creative groups vote to withdraw their support, annual Academy achievement awards probably will be abandoned." 65 This was the first union attempt not only to boycott but also to completely eliminate the awards and any benefits they might bring to producers.

This war of words in the Reorganization Committee finally led to action a few months later when Capra and SDG threatened to derail the awards of 1939. On February 16, a week before the ceremony and following a cancelled meeting with AMPP head Joseph Schenck, the guild's board of directors formally proposed a boycott of the awards at an emergency meeting. Capra would "immediately resign as president of the Academy, and withdraw as master of ceremonies;" the guild would then institute a studio-wide directors' strike following the event. 66 The next morning, The Hollywood Reporter's front page read, "The Screen Directors Guild last night moved to force an immediate showdown with the producers in the 18-month battle over recognition and a basic agreement. An ultimatum was issued to the producers, demanding that they sign a contract by 8 o'clock that night or accept the consequences." 67 The goal was to bring producers to the table and bring forth immediate final discussions with SDG. By the evening of February 17, AMPP conceded to SDG's demands, and the awards were held just days later. In a telegram to King Vidor, founding president of SDG, the board announced the contract arrangement:

As a result of Thursday night's meeting your board has received a letter from the Motion Picture Producers Association, signed by its president Joseph M. Schenck, recognizing our Guild as constituted, and accepting all points in our original program, with the exception of two which they assure us can be brought to a successful conclusion if we grant them three weeks time period accepting this as a declaration in good faith, your board has granted this request. 68 
Producers agreed to allow them to set up shop in all major studios with arbitration and conciliation, and "the Guild was to be the sole bargaining agent for directors and assistants." 69

The threatened SDG boycott reflected the Oscars' growth in prominence during the late 1930s. While the 1936 boycott drew attention to union issues, the 1939 boycott yielded more immediate results. At that time, the Academy was a struggling organization missing funds and membership from both the producers' and unions' sides. Since the last boycott, the Academy had spent three years effectively appeasing labor groups through policy changes and category additions. New trophies for best supporting actor and actress promised an even larger annual array of star power. The marketing draw of the awards had become a huge asset to production companies that was not worth risking in the face of SDG threats. Following these final negotiations between SDG and AMPP, SWG finally signed a standard contract in $1941 .{ }^{70}$ From that point on, actors, writers, and directors have held the right to participate in collective bargaining organizations that support their interests as employees of motion picture financiers.

Hollywood unionization during the 1930s can be seen as a part of the larger national labor movement that grew out of the Great Depression. New Deal bills such as the NIRA and the Wagner Act allowed new unions to form, organize strikes, and gain collective bargaining rights more effectively than in any previous decade. In 1933, President Roosevelt's first year in office, there were 1,695 attempted strikes across the country, over twice the number of the year before. ${ }^{71}$ Film industry professionals, however, utilized a unique set of bargaining tactics en route to gaining labor rights, seen most notably in the 1936 and 1939 attempted awards boycotts. The American public had more day-to-day awareness of movie stars, the films they were in, and the events they attended than they had of the average factory employee or labor-based workforce that was seeking organize in the 1930s. By harnessing the PR potential of the awards, unions gained lasting results: the boycott of 1936 received national awareness, and the SDG threat in 1939 led to a resolution of SDG contracting disputes. In this way, the Academy Awards played an instrumental role in Hollywood unionization.

As it restructured in 1937, withdrawing directly from industry matters, the Academy expanded its film appreciation mandate increasing its conservation department and making the Awards the organization's top priority. The reorganization of AMPAS prioritized the Hollywood workforce; this is perhaps nowhere better seen than in its new voting rules, which allowed all union membership to take part in the ballot for outstanding achievements and made the Oscars a true celebration of Hollywood by those in Hollywood. Paul McDonald notes in his book Hollywood Stardom that the "belief in the value of the Oscars is sustained by belief in the Academy as an authoritative organ for the industry." 72 While the open-voting rule only continued until 1946, the symbolic unification of the awards and film industry began during this period. AMPAS's conflict and eventual reunification with the creative guilds during the 1930s helped solidify the Academy into a nonpartisan institution for the commemoration and preservation of the movie business. Capra referred to the Oscars as "the most valuable, but least expensive, item of world-wide public relations ever invented by any industry." 73 Following this era of strikes, boycotts, and union animosity, the Academy Awards truly assumed its role as the ultimate night of glamour that both promoted and celebrated Hollywood's best and brightest. 
${ }^{1}$ Monica Sandler is a PhD student at the University of California, Los Angeles. She holds an MA and a BA from New York University. Her research focuses on historical and contemporary issues in American film industry labor, policy, and economics.

2 Frank Capra, Name Above the Title (New York: Macmillan, 1971), 268.

${ }^{3}$ Ibid.

${ }^{4}$ Murray Ross, Stars and Strikes: Unionization of Hollywood (New York: Columbia University Press, 1941); Steven Englund and Larry Ceplair, The Inquisition in Hollywood: Politics in the Film Community, 1930-1960 (Berkeley: University of California Press, 1983).

${ }^{5}$ Regarding the unionization of actors and SAG, see Danae Clark, Negotiating Hollywood: The Cultural Politics of Actors' Labor (Minneapolis: University of Minnesota Press, 1995), 82-118.

6 Pierre Norman Sands, A Historical Study of the Academy of Motion Picture Arts and Sciences (1927-1947) (New York: Arno, 1973).

7 Peter Decherney, Hollywood and the Cultural Elite: How the Movies Became American (New York: Columbia University Press, 2005).

8 Ibid., 211.

9 Interview with actor Conrad Nagel, a founding member and president of the Academy from 1932 to 1933, in Sands, A Historical Study, 33-34.

10 "Organization Banquet, the Reasons Why," 1927, Academy History Archive/Margaret Herrick Library Digital Collection (henceforth AHA/MHLDC), 1.

11 A complete list of all members at the start of the Academy was found in an early organizing brochure entitled "The Academy of Motion Pictures Arts and Sciences," June 20, 1927, AHA/MHLDC, 9-11. International membership in the Academy, meaning film-associated employees who did not work in the United State in some capacity, remained limited throughout the course of the 1930s, though it was not unheard of: Sergei Eisenstein actually joined the Academy in 1930. His international celebrity as a Russian filmmaker interested in the Academy was unusual enough to warrant an announcement in the Academy's monthly bulletin. See details at: "Bulletin, Number 40," September 21, 1931, AHA/MHLDC, 2. Membership gradually opened up in the 1940s following World War II, as distribution of films from the United Kingdom grew larger in American movie theaters. The earliest international attention to the Academy Awards came in 1939 when Jean Renoir's Grand Illusion (released in America in 1938) became the first foreign language feature to receive a nomination for Best Picture.

1267 Cong. Rec. 62,9657, June 29, 1922, found in Raymond Moley, The Hays Office (New York: Bobbs-Merrill, 1945), 27.

13 “Organization Banquet, the Reasons Why," 1927, AHA/MHLDC, 1.

14 Moley, The Hays Office, 48.

15 Sands, A Historical Study, 18-19.

16 Other major performing arts awards were established several decades after the Academy Awards had proven successful: the Tony Awards began giving out trophies in 1947, the Emmy Awards in 1949, and the Grammys in 1958.

17 Highlighting the instant appeal of the Awards throughout Hollywood, Frank Capra describes how his obsession with winning an Oscar began as early as the second Awards ceremony in 1930. He claims to have petitioned to join the Academy so that he could strategically campaign members for awards consideration. For Capra's account of his interest in the Academy Awards, see Capra, Name Above the Title, 116-17.

18 "Academy Constitution and By-Laws," 1927, AHA/MHLDC, 1. 
19 The Association of Motion Picture Producers, Inc. (AMPP) was established in 1924 as a united front for studio producers in all industrial workers relations problems. It served as the primary representative for producers during the 1920s and 1930s in matters of industry finance, workers policy, and unionization issues. Concise definition found in Moley, The Hays Office, 51.

${ }^{20}$ For an account of IATSE unionization and earlier writers and actors guilds, see Murray Ross, Stars and Strikes, 23-48.

21 Sands, A Historical Study, 40.

22 “Bulletin No. 1," June 1, 1927, AHA/MHLDC, 3.

${ }^{23}$ Membership count from "Academy Annual Membership Records," Margaret Herrick Library, AMPAS, Beverly Hills.

24 "Rules and nomination ballot, 1927/28 (1st) Academy Awards," 1929, AHA/MHLDC, 1.

25 For an account of the national bank closure of 1933, see Susan Estabrook Kennedy, The Banking Crisis of 1933 (Louisville: University Press of Kentucky, 1973), 152-203.

26 "Emergency Resolutions Related to Temporary Salary Reduction," March 7, 1933, AHA/MHLDC, 1-4.

27 Ross, Stars and Strikes, 42.

${ }^{28}$ In addition to granting collective bargaining rights to employees, the goals of the NIRA were to increase employment and purchasing power for companies badly hurt by the economic recession. The bill also established the National Recovery Administration (NRA) to regulate standard work codes and encourage care competition between companies in representing similar sectors. The NRA was a committee created by executive order of the president. Definitions of American labor court cases and bills during the 1930s found in Eric Arnesen, Encyclopedia of U.S. Labor and Working-Class History (New York: Routledge, 2007), 1:963-65.

${ }^{29}$ National Industrial Recovery Act, Ch. 90, 48 Stat. 195, Title I, Sec. 7(a), quoted in James A. Gross, The Making of the National Labor Relations Board: A Study in Economics, Politics and the Law, vol. 1, 1933-1937 (Albany: State University of New York Press, 1974), 10-11.

30 "Acad Almost Down, but Not Out; Fights for Chance to Keep Alive," Variety, January 23, 1934, 2.

31 "Academy Banquet Tonight a Sell-Out," Hollywood Reporter, March 16, 1934, 4.

32 "Academy Prizes," Variety, March 20, 1934, 61.

33 "Invitation, 1927/28 (1st) Academy Awards," May 1929, AHA/MHLDC. Italics are in the original quote.

34 “The Girl They Tried to Forget," Photoplay, January 1935, 26.

35 For an account of Bette Davis's 1930s career and feuds with Jack Warner and Warner Brother's Studios, see Thomas Schatz, "'A Triumph of Bitchery': Warner Bros., Bette Davis, and Jezebel," in The Studio System, ed. Janet Staiger (New Brunswick: Rutgers University Press, 1995), 74-92.

36 Cathy Klaprat, "The Star as Market Strategy: Bette Davis in Another Light," in The American Film Industry, ed. Tino Balio (Madison: University of Wisconsin Press, 1985), 357.

37 Joan Blondell, quoted in Joseph McBride, Frank Capra: The Catastrophe of Success (New York: Simon \& Schuster, 1992), 325.

38 Hollywood Citizen News, January 1935.

39 "Acad Allows Additional Nominations On Awards; Pressure for Bette Davis," Variety, February 20, 1935, 3.

40 Kathryn Dougherty, "Close-Ups and Long-Shots," Photoplay, March 1935, 23. 
${ }^{41}$ Capra went on to win two additional Best Director trophies and two Best Picture titles before the end of his presidency in 1939.

42 At the beginning of 1936, a public announcement explained that the AMPAS publicity department had added a new publicist, Vance King specifically tasked with handling awards banquets and awards planning. See "Chatter," Variety, January 15, 1936, 61.

43 Sands, A Historical Study, 95.

44 Capra, Name Above the Title, 188.

45 "Academy Votes Mutiny on the Bounty Best '35 Film," Film Daily, March 6, 1936, 1.

46 "Sold 10,000 Tickets," Variety, March 4, 1936, 33.

47 “Best Supporting Role Work to Get Academy Accolades," Film Daily, January 16, 1937, 6.

48 Telegram to Screen Actors Guild membership, March 2, 1936, Mary Pickford Papers, Margaret Herrick Library, Beverly Hills.

49 Dudley Nichols, public statement, found in "Nichols Turns Down Academy Statuette," Variety, March 11, 1936, 2.

50 Ruth Waterbury, "Close-Ups and Long-Shots," Photoplay, March 1936, 11.

51 "Picture Grosses," Variety, March 11, 1936, 8.

52 "Actor Is Artist-No, He's Laborer; Courts at Odds, Arbitration Hit," Variety, March 20, 1935, 1.

53 For further discussion of producer-controlled efforts to create a distinction between "artists" and "laborers" in Hollywood, see Decherney, Hollywood and the Cultural Elite.

54 This was not an issue in other creative arts fields like organized theater actors - whose union, Actors' Equity, had gained collective bargaining rights long before the labor issues of the 1930s. While theater producers may have tried to deter strikes and new contracting requirements, there was little question of whether or not stage actors had the right to their own unions. For an account of Actors' Equity and the unionization of theater workers, see Kerry Segrave, Actors Organize: A History of Union Formation Efforts in America, 1880-1919 (Jefferson, NC: McFarland, 2008).

55 The Supreme Court declared title 1 of the NIRA unconstitutional in May of 1935 after the court case Schechter Poultry Corp. v. United States. The decision specifically invalidated the National Recovery Administration, which had the ability to write regulatory law on a case-bycase basis, because the committee "usurped the legislature's power to create law." The case did not overturn workers' entitlements like collective bargaining written in NIRA. It did, however, lead to the development of the National Labor Relations Act (passed in June a month after the Supreme Court decision), which was designed to provide a legislative overview of US labor rights. Quote and definition found in Arnesen, Encyclopedia of U.S. Labor, 965.

56 For details regarding the development and legislation accomplished by the Wagner Act and the NLRB, see Gross, The Making of the National Labor Relations Board.

57 Sands, "A Historical Study," 224.

58 W. S. Van Dyke, Chairman of the Committee on Reorganization Policy, "Statement of Policy for Reorganized Academy," 1937, Special Collections, Margaret Herrick Library, AMPAS, Beverly Hills, 2.

59 “Acad. Activity Curtailed by Organizing Drives," International Projectionist, June 1937, 25.

60 "Rules and Nomination Ballot, 1937 (10th) Academy Awards," 1938, AHA/MHLDC, 2. 
${ }^{61}$ Christopher D. Wheaton, “A History of the Screen Writers' Guild (1920-1942): The Writer's Quest for a Freely Negotiated Basic Agreement" (PhD diss., University of Southern California, 1974), 142.

62 “J.L. Mahin Withdraws From Academy Screenplay Award," Film Daily, February 19, 1938, 1, 4.

63 Wheaton, "A History of the Screen Writers' Guild," 144.

64 “'Acad May Drop 'Oscars,'” Variety, September 28, 1938, 7.

65 Ibid., 19.

66 Capra, The Name Above the Title, 268.

67 “Directors Demand Showdown,” Hollywood Reporter, February 17, 1939, 1.

68 Telegram to King Vidor, Western Union, February 16, 1937, Special Collections, Margaret Herrick Library, AMPAS, Beverly Hills.

${ }^{69}$ Capra, The Name Above the Title, 270.

${ }^{70}$ In 1940, the SWG signed a deal with producers that contracted the guild for six months. The following year, the two parties finalized a seven-year agreement. For a full, detailed account of the SWG's standard contract negotiations with AMPP, see Wheaton, "A History of the Screen Writers' Guild."

${ }^{71}$ Bert Cochran, Labor and Communism: The Conflict That Shaped American Unions (Princeton, NJ: Princeton University Press, 1977), 84.

72 Paul McDonald, Hollywood Stardom (Malden: Wiley-Blackwell, 2013), 1969.

73 Frank Capra, The Name Above the Title, 187.

\section{Bibliography}

Arnesen, Eric. Encyclopedia of U.S. Labor and Working-Class History. New York: Routledge, 2007.

Capra, Frank. The Name Above the Title. New York: Macmillan, 1971.

Gross, James A. The Making of the National Labor Relations Board: A Study in Economics, Politics, and the Law. Vol. 1, 1933-1937. Albany: State University of New York Press, 1974.

Kennedy, Susan. The Banking Crisis of 1933. Louisville: University Press of Kentucky, 1973.

Klaprat, Cathy. "The Star as Market Strategy: Bette Davis in Another Light." In The American Film Industry, edited by Tino Balio, 351-76. Madison: University of Wisconsin Press, 1985.

McBride, Joseph. Frank Capra: The Catastrophe of Success. New York: Simon \& Schuster, 1992.

Moley, Raymond. The Hays Office. New York: Bobbs-Merrill, 1945.

Ross, Murray. Stars and Strikes: The Unionization of Hollywood. New York: Columbia Press, 1941.

Sands, Pierre Norman. A Historical Study of the Academy of Motion Picture Arts and Sciences (19271947). New York: Arno, 1973.

Schatz, Thomas. "'A Triumph of Bitchery': Warner Bros., Bette Davis, and Jezebel." In The Studio System, edited by Janet Staiger. New Brunswick, NJ: Rutgers University Press, 1995.

Segrave, Kerry. Actors Organize: A History of Union Formation Efforts in America, 1880-1919. Jefferson, NC: McFarland, 2008. 
Wheaton, Christopher D. “A History of the Screen Writers' Guild (1920-1942): The Writer's Quest for a Freely Negotiated Basic Agreement." PhD diss., University of California, 1974.

\section{(cc) BY-NC-ND}

Copyright (c) 2015 (Monica Sandler). Media Industries is an open-access, peer-reviewed, online academic journal. As such, we aim to participate in the open exchange of information. This work is licensed under a Creative Commons Attribution Noncommercial No Derivatives (by-nc-nd) License. Under this license, this work is available for sharing and noncommercial distribution provided the appropriate attribution is given. 